\title{
Supporting individuals with autism spectrum disorder in understanding and coping with complex social emotional issues
}

\author{
Kaitlyn P. Ahlers \\ University of Montana \\ Terisa P. Gabrielsen \\ Brigham Young University, terisa_gabrielsen@byu.edu \\ Danielle Lewis \\ Brigham Young University \\ Anna M. Brady \\ Utah State University \\ April LItchford \\ Utah State University
}

Follow this and additional works at: https://scholarsarchive.byu.edu/facpub

Part of the Communication Sciences and Disorders Commons, and the Psychiatry and Psychology Commons

\section{BYU ScholarsArchive Citation}

Ahlers, Kaitlyn P.; Gabrielsen, Terisa P.; Lewis, Danielle; Brady, Anna M.; and Lltchford, April, "Supporting individuals with autism spectrum disorder in understanding and coping with complex social emotional issues" (2017). Faculty Publications. 2157.

https://scholarsarchive.byu.edu/facpub/2157

This Peer-Reviewed Article is brought to you for free and open access by BYU ScholarsArchive. It has been accepted for inclusion in Faculty Publications by an authorized administrator of BYU ScholarsArchive. For more information, please contact ellen_amatangelo@byu.edu. 


\section{Supporting Individuals with Autism Spectrum Disorder in Understanding and Coping with Complex Social Emotional Issues}

All individuals face the challenge of learning how to manage complex social emotional issues. Over time, we develop the resilience and skills to navigate life's challenges, including shouldering stressful responsibility, meeting deadlines, coping with grief following the death of a loved one, repairing damaged relationships, and surviving traumatic events. However, we are not alone in meeting these challenging situations. We acquire social emotional skills through life experiences and with the support of peers, family, caregivers, and teachers. These key people help us to incorporate our personal strengths into adaptive coping and learning strategies (McCrimmon, Matchullis, \& Altomare, 2016). This is a difficult process for most, but for individuals with autism spectrum disorder (ASD) the need for informed, individualized, and effective support is especially critical. Unfortunately, meeting the social emotional needs of this unique population may exceed the existing skill sets of many parents, educators, and school psychologists.

\section{ASD and Implications for Addressing Social Emotional Needs}

Although each person with ASD is unique, there are common categories of symptoms that define the disorder (American Psychiatric Association [APA], 2013). Key diagnostic markers include social communication deficits, reflecting difficulties with the give-and-take of social interactions (social reciprocity); difficulties with nonverbal communication behaviors (e.g., eye contact, gestures, facial expressions, and nonverbal social cues); and deficits in developing, maintaining, and understanding relationships. Additionally, restricted and repetitive behaviors, difficulties with changes in routine, and sensory hyper- or hypo-sensitivity may also 
be present. Some with ASD also have intellectual disability and language impairment (APA, 2013). Without supports that are specifically suited for individuals with ASD, each of these challenging symptoms pose significant obstacles to social emotional learning.

As the global prevalence of individuals identified with ASD increases (Elsabbaugh et al., 2012), more diversity and a broader spectrum of symptoms and impairments are evident (TagerFlusberg \& Joseph, 2003). Additionally, regardless of their unique symptoms, individuals with ASD face similar complex social issues, particularly in relation to anxiety, social isolation, and emotions associated with grief or loss.

For example, consider the case of Rajh, a ten-year-old male with ASD. Rajh has ageappropriate language and cognitive abilities, but needs behavioral support in school because of his heightened anxiety, typically triggered by changes in routine. Prior to this year, he reported being happy at school and home. However, this year his parents divorced. Additionally, he is noticing that classmates do not include him in games and conversations. He is also experiencing more bullying from his peers. Previously not easily provoked, Rajh is now aggressive with peers, hitting, pushing, and shoving when frustrated. These aggressive behaviors are noted across settings.

Rajh's support needs are complexly intertwined - he is facing significant anxiety in everyday situations, he is experiencing social isolation, and he is saddened by his parents' divorce. In addition to the supports he has typically received to help him cope with anxiety, he now needs targeted supports that address social isolation and grief and loss.

Anxiety and social isolation are frequently occurring issues for individuals with ASD. Researchers estimate that anxiety disorders co-occur in approximately $40 \%$ of individuals with ASD, though rates between $11 \%$ and $84 \%$ have been reported in community- and clinic-referred 
samples (van Steensel, Bögels, \& Perrin, 2011; White, Oswald, Ollendick, \& Scahill, 2009).

Among the findings of The National Longitudinal Transition Study-2012 (NLTS-2012),

adolescents with ASD reported low rates of seeing friends outside of school (29\%, compared to $52 \%$ of all children with disabilities); and communicating with friends by text, social media, or phone ( $22 \%, 18 \%$, and $20 \%$ for ASD compared to $54 \%, 43 \%$, and $38 \%$ of all with disabilities). These data indicate much higher levels of social isolation for adolescents with ASD than for students with intellectual disabilities or multiple disabilities (Lipscomb et al., 2017). As such, response to loss (e.g., parents' divorce, death of a loved one, separation from a loved one, etc.) may be magnified and complicated by pre-existing anxiety, social communication deficits, and social isolation.

\section{Purpose and Overview}

Noting the complexity and interconnectedness of social emotional challenges associated with anxiety, social isolation, and grief, in this article we will address each of these topics. First, we will explore misconceptions about individuals with ASD; then, we will identify appropriate intervention strategies and supports that are grounded in research and practice. We also provide tables and appendices with resources to assist parents, teachers, and therapists (including school psychologists, counselors, and mental health professionals) in more effectively supporting the social emotional needs of youth with ASD. Although the majority of resources given are designed for individuals with some language abilities, many are adaptable for minimally verbal individuals.

\section{Misconceptions About Individuals with ASD}

In this section we will discuss three common misconceptions related to the social emotional needs of individuals with ASD. These three misconceptions include the following: (a) 
anxiety is just part of ASD (Mason \& Scior, 2004); (b) individuals with ASD don't want friends (Autism Speaks Family Services and Science Dept. [Autism Speaks], 2017; and (c) individuals with ASD can't express emotions and can't understand the emotions of others (Autism Speaks, 2017).

Misconception: Anxiety is just part of ASD. Anxiety is a general term encompassing multiple disorders with adverse emotional reactions to specific fears of real or perceived imminent threat (phobias), or anticipation of future threats in specific situations (social anxiety, separation anxiety), or sometimes less specific threats (generalized anxiety). In the presence of anxiety symptoms, individuals alter their behaviors, often limiting their ability to function (APA, 2013). Recognizing that individuals with ASD experience anxiety is not new, as Kanner (1943) observed that numerous children with classic autism had substantial problems with anxiety. However, until recently, the research on the relationship between anxiety and autism has been sparse. Mason and Scior (2004) postulated that diagnostic overshadowing (i.e., ignoring the presence of mental health symptoms because they seem to be part of another disability, in this case ASD) might have contributed to the delayed exploration of anxiety symptoms in individuals with ASD. During the past decade there has been a proliferation of research examining the manifestation of anxiety in individuals with ASD, including meta-analyses that show anxiety to be more prevalent (31 studies: van Steensel et al., 2011) and more elevated (83 studies: van Steensel \& Heeman, 2017) in children with ASD, especially in children with higher cognitive function. Some of the most common anxiety disorders reported with ASD are generalized anxiety disorder, separation anxiety disorder, social anxiety disorder, and phobias (White et al., 2009). 
Researchers have recently begun asking whether symptoms of anxiety are to be expected as an appropriate response to daily challenges or whether these symptoms are indicative of a comorbid psychological disorder in need of targeted intervention to reduce impairment (Kerns et al., 2014). If anxiety disorders and ASD co-occur as comorbid disorders, anxiety symptoms in individuals with ASD should match the symptoms of anxiety disorders as defined by the Diagnostic and Statistical Manual of Mental Disorders-5th ed. (DSM-5; APA, 2013). For instance, a child may be resistant to socially engage with same-aged peers for several reasons, including anxiety-related fears of being negatively evaluated by peers (i.e., social anxiety disorder), ASD-related social skills deficits, or an interaction of both disorders (Renno \& Wood, 2013). Thus, there may be a two-way relationship between social anxiety disorder and ASDrelated social skill deficits, as social anxiety could be both a result of and contributor to social awkwardness and avoidance of social interactions (Kerns \& Kendall, 2012; White et al., 2009).

In a study of youth between ages 7-17 who were diagnosed with ASD, Kerns and colleagues (2014) observed traditional (consistent with DSM criteria) anxiety disorders in $48 \%$ of the sample. The anxiety symptoms were independent of ASD severity and were associated with well-known predictors of anxiety in youth without ASD (e.g., a more anxious cognitive style, sensory hypersensitivity), suggesting that traditional anxiety, as it presents in typically developing children, may also occur in individuals with ASD (Kerns et al., 2014).

Kerns and colleagues (2014) also found the presence of atypical anxiety symptoms, which were considered qualitatively different from the traditional anxiety disorder categories and were possibly linked to difficulties specifically common to individuals with ASD. Some examples of anxiety symptoms that would be considered atypical include excessive and interfering worries regarding schedule changes; specific phobias with an unusual focus (e.g., 
running water, men with beards); and consistent social discomfort and fearfulness, not stemming from the fear of negative social evaluation (Kerns et al., 2014). These findings illustrate both separate and ASD-specific anxiety types.

Researchers have noted that individuals with ASD develop anxiety for many of the same reasons that individuals without ASD develop anxiety disorders. furthermore, family psychiatric difficulties - that may be transmitted by genetics, social-environmental factors, or both - may be risk factors that trigger and exacerbate anxiety in individuals with ASD (Kerns, Rump, et al., 2016). Age and developmental level should be considered, as Davis and colleagues (2011) demonstrated that the trajectory of anxiety symptoms in individuals with ASD approximates that of typically developing individuals (i.e., peaking in adolescence). Additionally, negative life events, difficulties with emotion regulation and hyperarousal, and skill deficits (e.g., deficits in social skills, daily living skills, and academic proficiency) may increase the likelihood of individuals with ASD developing anxiety disorders (Bellini, 2006;Kerns, Newschaffer, \& Berkowitz, 2015; Kerns, Rump, et al., 2016).

Misconception: Individuals with ASD don't want friends. Despite central deficits in social communication in ASD, not all individuals with ASD experience negative social outcomes and require intensive intervention in school settings (Locke, Williams, Shih, \& Kasari, 2017). Many individuals with ASD are capable of forming reciprocal friendships (Bauminger et al., 2008a, 2008b; Kasari, Locke, Gulsrud, \& Rotheram-Fuller, 2011). However, the capacity to form friendships does not guarantee that these individuals are included socially by their peers (Locke et al., 2017). Locke, Ishijima, Kasari, and London (2010) found that individuals with autism experience loneliness and also recognize the poor quality of their friendships. 
Jones and Frederickson (2010) noted that those with ASD who were rated as having prosocial behaviors were not necessarily included in social interactions with peers. Some peers purposefully exclude individuals with ASD. For example, peer-bullying and a lack of education on the part of both typical peers and teachers have been identified as factors contributing to social isolation (Majoko, 2016). Ultimately, regardless of who is to blame, difficulty connecting with others leads to individuals with autism feeling lonely and socially isolated (Ozonoff, Dawson, \& McPartland, 2002). For example, the NLTS-2012 reported 45\% of youth with autism choose to do activities with their friends, and $76 \%$ report knowing how to make friends (both significantly lower rates than other disabled peers). Peers with intellectual disability (ID) reported similar rates of choosing activities with friends (48\%), but more consistent, higher rates of weekly get-togethers (42\% for ID vs. $29 \%$ for ASD). Although those with ASD and comorbid ID were not separately identified, $50 \%$ of the ASD sample reported difficulty communicating by any means (compared to $60 \%$ in the ID group) and similar rates of not being able to understand what people say to them (70\% and 69\%, ASD and ID respectively), so it is likely that the results reflect individuals across the spectrum of cognitive abilities. Taken together, these findings indicate that though many individuals with autism desire to have friends, they are not as successful in engaging socially with friends (Lipscomb et al, 2017).

\section{Misconception: Individuals with ASD can't express emotions and can't understand}

the emotions of others. Prior to 1960, minimal research was conducted on the effects of grief and loss (Forrester-Jones \& Broadhurst, 2007). Grief is a complex emotion that is manifest in different ways in children than adults. Symptoms may include behavior changes as well as attempts at emotional expression. Children and adolescents may grieve intermittently and can re-experience grief as they develop and gain more understanding (Himebauch, Arnold, and May, 
2008). Very little research has been done on the effects that grief has on those with autism, so most information available is from websites or books from people who have worked with children with autism who are grieving. It is sometimes erroneously assumed that individuals with autism lack the ability to empathize with others and that they have no connection with or insight into their own emotions. Behavioral outbursts displayed during times of stress tend to reinforce this misperception. However, while those with autism might grieve in ways that differ from typical expressions of grief, researchers acknowledge that these individuals grieve (Lipsky, 2013).

At times, individuals with ASD might focus solely on their own schedule and routines and appear disinterested in the death of a loved one. However, during stressful times, routines give them a comforting sense of order. The need for this order may dominate the thoughts of individuals with ASD and this preoccupation may give the impression that they are indifferent to the loss. In reality, this preoccupation may be their way of managing strong emotions associated with grief.

Following the death of a loved one or other significant loss, communication difficulties are common for individuals with ASD due to limited language abilities, a lack of social understanding regarding situations involving grief, and a lack of motivation to respond in a socially acceptable manner (APA, 2013). When general rules of social interaction are not followed, the individual may appear rude and disinterested. The individual may ask questions that seem awkward or inappropriate. Additionally, the individual may impulsively make comments without considering how these comments affect others. An individual with autism may have a difficult time interpreting others' feelings or the way others are perceiving the situation. Likewise, others may misunderstand what an individual with ASD is trying to convey, 
due to distracting body movements and facial expressions that are incongruent with the individual's feelings (Helbert, 2013).

\section{Strategies to Support the Social Emotional Needs of Students with ASD}

Providing social emotional supports to students with ASD is primarily a teaching/learning process. In addition to specific interventions (i.e., cognitive behavior therapy, social skills packages and peer training packages discussed later), several learning strategies have been identified as established interventions to improve outcomes for students with ASD (National Autism Center [NAC], 2015a, 2015b). Among this list are four strategies well-suited to social and emotional support that may be part of package interventions. These strategies include schedules, modeling, story-based interventions, and scripting, each of which can also be effective as standalone interventions across the spectrum of language and cognitive abilities. In the following paragraphs, these strategies are briefly described.

Schedules involve using a chart or list with pictures or words that show sequential activities or ordered steps throughout a discrete event (e.g., getting ready for school) or the entire day. Charts can be created to teach independence in routines or to decrease anxiety about a new situation (Knight, Sartini, \& Spriggs, 2015). Using positive reinforcement, a child can also be taught to accept the unexpected by practicing (allowing for) at least one unexpected event each day, with a reward for showing positive or neutral reactions when the unexpected event occurs. For example, a schedule might prepare a child for an assembly at school or a field trip as departures from typical routines, or changes in routines following a loss. Resources for schedules are included in Appendix A [insert link to App. A here].

Our second strategy is modeling. In this strategy, appropriate, situation-specific, social behaviors are modeled on video by others or by the individual. Then, children watch the video. 
After watching the video, children practice the skills and receive feedback. Since the original research of video modeling conducted by Bandura, Ross, and Ross (1963), this technique has been strongly supported in the literature. This strategy is also effective with students with ASD, particularly when teaching a new skill (Bellini \& Akullian, 2007). Some research has shown video modeling to be superior to live modeling (Charlop-Christy, Le, \& Freeman, 2000; McCoy \& Hermansen, 2007). Video modeling has also become increasingly affordable and accessible with rapid advances in technology and personal electronic devices (Kellems \& Morningstar, 2012). Modeling can be used to show what to expect and what to do at a funeral or how to deal with bullying, for example. Modeling resources are listed in Appendix A [insert link to App. A here].

The next strategy is based on the power of a story to help increase understanding and compliance in children with autism. Story-based interventions are practical, easy to implement, and effective. The most popular and most widely used story-based interventions include Social Stories $^{\mathrm{TM}}$ developed by Carol Gray (2010). These brief structured stories use visual information (simple drawings, pictures, photos, or video) with a short narrative to clearly and simply state what the individual will encounter in a given social situation, how to respond or act in a socially appropriate way, and the subsequent rewards and/or satisfaction for acting in a socially appropriate manner. Research indicates that social stories help children improve their social interactions (Stary, Everett, Sears, Fujiki, \& Hupp, 2012). A social story may portray how to ask to join a game at recess, for example. Story-based resources are listed in Table 2.

The last of the four strategies is scripting. Scripting involves practicing (in advance) what to say in common social situations. This advance practice helps individuals with ASD appropriately join social interactions (Bellini \& Peters, 2008). Scripting may also help 
individuals with ASD to avoid saying impulsive and unintentionally hurtful comments. For example, when a peer is grieving the loss of a loved one, the individual with ASD will practice and deliver a scripted statement, such as "I am so sorry for your loss." Resources that include scripting strategies are included in Appendix A [insert link to Appendix A here].

\section{Interventions for Anxiety and ASD}

Researchers have demonstrated that self-injurious behavior, depressive symptoms, parental stress, social skill deficits, and decreases in academic performance are associated with the co-occurrence of anxiety and ASD (Kerns, Kendall, et al., 2015; Sze \& Wood, 2007). These difficulties, on top of difficulties associated with symptoms of anxiety, provide strong evidence regarding the need for anxiety-focused treatment in individuals with ASD (Kerns, Rump, et al., 2016). Moreover, researchers have demonstrated that without intervention, anxiety in individuals with ASD does not diminish, but extends across the life span (McNally Keehn, Lincoln, Brown, \& Chavira, 2013). Importantly, Kerns, Kendall, and colleagues (2015) noted that interventions directed solely towards ASD might not adequately address the interaction of anxiety and ASD. Therefore, evidence-based treatments for the co-occurrence of anxiety and ASD are critically important.

Kerns, Wood, and colleagues (2016) noted that several characteristics of individuals with ASD - such as their social communication deficits, restricted and repetitive behaviors, limited insight, and unique expressions of anxiety - might lessen the effectiveness of standard practice cognitive behavioral therapy (CBT) for individuals with anxiety. Consequently, CBT protocols for anxiety have been adapted to more adequately address the needs of individuals with ASD and shown to improve symptoms in multiple randomized control trials and through meta-analysis (Spain, Sin, Chalder, Murphy, \& Happe, 2015; Reaven, Blakely-Smith, Culhane-Shelburne, \& 
Hepburn, 2012; Storch et al., 2013; Sukhodolsky, Bloch, Panza \& Reichow, 2013; Ung, Selles, Small, \& Storch, 2015; Vasa et al., 2014, Wood et al., 2009, Wood et al., 2015).

The recent meta-analysis to examine the efficacy of 14 studies involving 511 participants with high-functioning ASD concluded that CBT was moderately effective for individuals with high-functioning ASD. Additionally, they outlined the common components of CBT that were used across the studies included in the meta-analysis. These components included psychoeducation, creation of a fear hierarchy, exposure to feared stimuli, cognitive restructuring, relaxation techniques, and social skill development. Furthermore, in order to modify the protocols to better suit individuals with ASD, adaptations included the use of role play, visual aids, structured worksheets, social stories, video modeling, and a wide variety of reinforcement strategies (Ung et al., 2015). Along with these adaptations, other researchers recommend modifying CBT procedures to tap into special interests of individuals with ASD (Vasa et al., 2014) and slow down the pace of the CBT sessions to allow extra processing time for individuals with ASD and co-occurring intellectual disabilities (Spain et al., 2015). Additionally, the specific treatment protocols used across studies were based on treatment manuals. The effects of CBT adapted for individuals with ASD have been shown in the same magnitude as the wellestablished effects of CBT in typically developing individuals (Sukhodolsky, Bloch, Panza \& Reichow, 2013).

While the majority of studies on using modified CBT for individuals with highfunctioning ASD have been conducted in clinical settings, Luxford, Hadwin, and Kovshoff (2016) conducted a randomized controlled trial measuring the effectiveness of a school-based CBT intervention with adolescents who were identified with ASD. Notably, Luxford and colleagues (2016) demonstrated that, in comparison to a waitlist control group, adolescents with 
ASD showed a greater reduction in anxiety symptoms and that these improvements were maintained at six weeks post intervention. Furthermore, parents and teachers were included in the manualized CBT intervention. Additionally, the successful results of this study generalized across settings. This study's intervention was based on Attwood's (2004) book that is listed in Table 1. Other manuals and resources are listed in Appendix B [insert link to App. B here].

Rosen, Connell and Kerns (2016) highlighted that CBT is a verbally demanding treatment and includes a focus on labeling emotions, abstract thinking, and verbal coping strategies (e.g., cognitive restructuring, problem solving). Considering these demands, CBT may be a poor fit for individuals on the autism spectrum who have lower verbal abilities. However, they provided preliminary evidence that behavioral treatments with lower functioning individuals with ASD are efficacious and might be a promising avenue for anxiety treatment for individuals who struggle with higher levels of symptom severity, intellectual disability, and/or significant language impairment. They summarized common treatment components across studies, including desensitization, reinforcement, modeling, and prompting.

\section{Interventions for Social Isolation}

There are two basic approaches to improve outcomes for individuals with ASD who are socially isolated (Kasari et al., 2011; NAC, 2015a, 2015b). The first is a skill-building approach to increase appropriate social interactions and motivations through direct instruction, social stories, and scripting (NAC, 2015a, 2015b). The other approach is to increase the capacity of peers to include students with ASD in age-appropriate peer activities (Kasari et al., 2011).

There are numerous published social skills intervention programs designed specifically to build social interaction and communication skills in individuals with ASD. Some, such as the University of California, Los Angeles (UCLA) Program for the Education and Enrichment of 
Relational Skills, or PEERS ${ }^{(\mathrm{R})}$ curriculum, have been researched as a stand-alone package (Laugeson, Frankel, Mogil, \& Dillon, 2009); replicated by Schohl et al. (2014); and implemented across cultures and languages (Yoo et al., 2014). Although other curricula may not have this level of package-specific evidence, many programs incorporate established elements of effective social skills interventions. Programs that include the following evidence-based components are identified as established interventions: (a) group instruction with typical peers in the group; (b) clear, concrete social rules; (c) generalization opportunities (e.g., free time to play or talk, field trips, homework); (d) high interest, hands on, fun, age-appropriate activities; (e) self-monitoring of social behaviors; (f) video modeling and/or role plays; (g) social stories or social scripts; (h) structured and predictable sessions; (i) progression of skills with errorless teaching; and (j) positive reinforcement for demonstration of skills and "homework" completion (Gresham, Sugai, \& Horner, 2001; Krantz \& McClannahan, 1993; Krasny, Williams, Provencal, \& Ozonoff, 2003; NAC, 2015a, 2015b; Williams White, Keonig, \& Scahill, 2007). Social skills intervention packages with these elements have been shown to increase communication skills, learning readiness, and play while decreasing general ASD symptoms and problem behaviors. Social skills package interventions have also shown effects of decreasing socially isolating behaviors such as engaging in restricted and repetitive behaviors and sensory or emotional regulation difficulties (NAC, 2015a, 2015b).

Peer training is also an established intervention for students with autism (NAC, 2015a, 2015b). Multiple approaches for changing peer behaviors have been shown to decrease social isolation in students with ASD. Kasari and colleagues (2011) worked with elementary-aged peers each week to teach strategies for involving students who were not included (without specifically mentioning students who were identified with ASD). During recess, trained peers 
were then observed. Observations and data indicated that trained peers spontaneously engaged with students with ASD and nominated these students more often as a peer they would like to play with or who was their friend (Kasari et al., 2011). Ochs, Kremer-Sadlik, Solomon, and Sirota (2001) found that when students (ages 8-12) with ASD disclosed their diagnosis to peers, peers' social support increased. Another approach with middle-school typical peers (ages $12-$ 15) was to include first person narrative information (self-introduction) about ASD. First person narrative information resulted in increased positive attitude about students with ASD (Campbell, 2007).

When implementing interventions that include typical peers, one of the more challenging aspects is finding typical peers who are able to attend the group. This difficulty is perhaps due to concerns about taking typical peers from class to participate in social skills interventions. To encourage parents and teachers to include typical peers, it may be helpful to cite Asmus et al. (2017). They found that typical high school peers engaging in peer support networks showed their own academic improvements following participation in social interactions with students identified with disabilities. To assist schools in implementing interventions to improve social skills specific to ASD, five resources are listed in Table 2. A more extensive list is included in Appendix C [insert link to Appendix C here].

Additionally, Carter, Hughes, Copeland, and Breen (2001) found that in comparison to those high school students who did not volunteer, adolescents who volunteered in peer training programs experienced more growth in knowledge and willingness to interact with students with disabilities. Their research also indicated that peer training programs helped to reduce the social isolation of students with disabilities. Later research found that the proximity of a typical peer increased the frequency of social interactions and positive social skills of the student with 
disabilities (Carter, Hughes, Guth, \& Copeland, 2005). Finally, based on applied practice, Maich and Belcher (2012) outlined 10 principles for choosing bibliotherapy resources (picture books) to teach peers about ASD. Specific titles and resources are listed in Table 2 and Appendix C [insert link to Appendix $\mathrm{C}$ here].

\section{Interventions for Coping with Grief}

The intersection of research on autism and grief is just beginning to emerge in the literature. Only one published article (not a research study) was found on supports for grief in children with developmental disabilities (Sormanti \& Ballan, 2011) along with one unpublished dissertation which addressed grief in children with autism spectrum disorder specifically with a video game intervention (Johnson, 2016). Following a death or loss, an individual with ASD will face many challenging social situations: Others may attempt to offer the individual comfort; the individual may want to comfort others in their grief; in the case of a death, the individual may attend an open-casket viewing of the deceased loved one; and the individual may attend the funeral or memorial service.

According to Ozonoff, Dawson, and McPartland (2002), current research has shown that social scripts (scripting) can be useful tools for helping to prepare those with autism for unfamiliar social situations. This could be beneficial in preparing them for how to handle events relating to death. Scripts offer individuals specific phrases to use in these situations, which could offer the individual guidance for an event such as a funeral or memorial service. As individuals with autism may not have appropriate existing social scripts, this advanced preparation can help the individual feel more comfortable in their interactions with other grieving individuals. Social Stories $^{\mathrm{TM}}$ (Gray, 2010) are designed to preemptively prepare the individual for typical social situations before encountering them. Ozonoff et al. (2002) state that rather than solely offering 
exact phrases to use in situations, social stories focus more on critical social cues, why people are behaving in certain ways, and why it is important to respond in a particular manner For example, a story can be created (using any medium) to describe what will happen at a funeral, what will happen when people try to offer comfort, and what will happen at school when the individual feels the intense sadness associated with loss. Social stories have the added benefit of reducing anxiety by showing the child what to expect. Because social stories are designed for repetition, the stories could also offer comfort by reviewing what happened in the past (similar to a memory book), including the feelings and actions of people in the story.

Wharff (2015) stated that although those with autism benefit from advanced preparation for changes that might alter their normal routines, this is not always possible. When an unexpected event occurs (e.g., the sudden death of a loved one, divorce, a loved one moving away, military deployment) multiple unplanned changes in daily routines are inevitable. Following a death or substantial loss, life becomes chaotic. According to Helbert (2013), the ensuing disorder, confusion, and uncertainty often contribute to emotional outbursts. Anxiety associated with the uncertainty may be reduced by making a schedule of the altered routines, so the events of the day become more predictable.

Wheeler (2016) states that interventions based on principles of CBT, adapted for children with autism, may support an individual with ASD through their grief process and help the individual become more aware of their thoughts, emotions, and behaviors. According to Wheeler, as an individual becomes more aware of the way they think, they are able to have more control over their actions and outward expressions. Family and teachers need to consider that it may take longer for a child or adolescent with ASD to learn to cope with grief and that the effects of grief may be more unpredictable than in typically developing individuals. In the grief 
process, individuals with ASD may become "stuck" on an idea (perseverative interests; APA, 2013, p. 50). This rigidity may restrict adaptive coping and the ability to manage feelings associated with grief, and continued support will be needed. To help children learn to cope with their grief, Table 3 and Appendix D [insert link to Appendix D here] include user-friendly resources, including children's books.

\section{Case Example}

Returning to the case of Rajh, who is experiencing everyday anxiety associated with autism, increasing social isolation and bullying, and grief over his parents' divorce, several available resources can help his family, teachers, and therapists to address his needs. Because of his age-appropriate verbal ability, he is likely to respond well to CBT techniques adapted for children with autism, including the support of modeling and the concrete visual models for linking feelings and thoughts to actions, such as those provided in The Incredible 5-Point Scale book (details about this resource are listed in Table 2). Using the scale format and/or the anxiety curve can help him learn skills to gain self-control and better regulate his emotions. Using these therapeutic and visual tools, he can be better prepared to his use CBT coping strategies for anxiety when faced with changes in routine. As his feelings about his parents' divorce overwhelm him, these same resources can help him to know what he can do to feel better. Rajh can also benefit from modeling as part of a social skills intervention group to improve his own social skill levels and allow him safe opportunities for supported, successful socialization at school. Individualized Social Stories ${ }^{\mathrm{TM}}$ and scripting can teach him specifics of what to do and say when he experiences bullying and social isolation. Finally, reducing levels of anxiety using schedules (e.g., days he will be spending at Dad's or Mom's house, how he will get to school, 
who will pick him up, and what will be happening each day) can reduce the overall burden of social-emotional stressors in Rajh's everyday life.

\section{Conclusion}

The resources that are included in this article's tables and appendices are offered to assist caring adults is supporting children with ASD who are experiencing anxiety, social isolation and grief. Many individuals with ASD experience anxiety and social isolation on a regular basis. Additionally, although a universal experience, grief is complicated by deficits in social communication and emotional understanding that are inherent in ASD. Intervention packages (i.e., CBT, social skills instruction, and peer training) can make use of established strategies such as schedules, modeling, story-based interventions, and scripting to specifically increase social emotional understanding and skill in individuals with ASD. Caregivers, educators, mental health professionals, and peers can provide needed support as individuals with ASD learn strategies for understanding and coping with complex social emotional issues.

\section{References}

American Psychiatric Association. (2013). Diagnostic and statistical manual of mental disorders (5th ed.). Arlington, VA: Author.

Asmus, J., Carter, E. W., Moss, C. K., Biggs, E. E., Bolt, D. M., Born, T. L.,...Wier, K. (2017). Efficacy and social validity of peer network interventions for high school students with severe disabilities. American Journal on Intellectual and Developmental Disabilities, 122(2), 118-137. doi: 10.1352/1944-7558-122.2.118

Attwood, T. (2004). Exploring feelings: Cognitive behaviour therapy to manage anxiety. Arlington, TX: Future Horizons. 
Autism Speaks Family Services and Science Department (2017). 11 myths about autism. Retrieved from https://www.autismspeaks.org/node/113471

Bandura, A., Ross, D., \& Ross, S. (1963). Imitation of film-mediated aggressive models. Journal of Abnormal and Social Psychology, 66, 3-11. doi: 10.1037/h0048687

Bauminger, N., Solomon, M., Aviezer, A., Heung, K., Brown, J., \& Rogers, S. J. (2008a). Children with autism and their friends: A multidimensional study of friendship in highfunctioning autism spectrum disorder. Journal of Abnormal Child Psychology, 36, 135150. doi: $10.1007 / \mathrm{s} 10802-007-9156-\mathrm{x}$

Bauminger, N., Solomon, M., Aviezer, A., Heung, K., Brown, J., \& Rogers, S. J. (2008b). Friendship in high-functioning children with autism spectrum disorder: Mixed and nonmixed dyads. Journal of Autism and Developmental Disorders, 38, 1211-1229. doi: 10.1007/s10803-007-0501-2

Bellini, S. (2006). The development of social anxiety in adolescents with autism spectrum disorders. Focus on Autism and Other Developmental Disabilities, 21, 138-145. doi: $\underline{10.1177 / 10883576060210030201}$

Bellini, S., \& Akullian, J. (2007). A meta-analysis of video modeling and video self-modeling interventions for children and adolescents with autism spectrum disorders. Exceptional Children, 73, 264-287. doi: 10.1177/001440290707300301

Bellini, S., \& Peters, J. K. (2008). Social skills training for youth with autism spectrum disorders. Child and Adolescent Psychiatric Clinics of North America, 17, 857-873. doi: 10.1016/j.chc.2008.06.008 
Campbell, J. M. (2007). Middle school students' responses to the self-introduction of a student with autism: Effects of perceived similarity, prior awareness, and education message. Remedial and Special Education, 28, 163-173. doi: 10.1177/07419325070280030501

Carter, E. W., Hughes, C., Copeland, S. R., \& Breen, C. (2001). Differences between high school students who do and do not volunteer to participate in a peer interaction program. Research and Practice for Persons with Severe Disabilities, 26, 229-239. doi: $\underline{10.2511 / \mathrm{rpsd} \cdot 26.4 .229}$

Carter, E. W., Hughes, C., Guth, C. B., \& Copeland, S. R. (2005). Factors influencing social interaction among high school students with intellectual disabilities and their general education peers. American Journal on Mental Retardation, 110, 366-377. doi:

\subsection{2/0895-8017(2005)110[366:FISIAH]2.0.CO;2}

Charlop-Christy, M. H., Le, L., \& Freeman, K. A. (2000). A comparison of video modeling with in vivo modeling for teaching children with autism. Journal of Autism and Developmental Disorders, 30, 537-552. doi: 10.1023/A:1005635326276

Davis, T. E., Hess, J. A., Moree, B. N., Fodstad, J. C., Dempsey, T., Jenkins, W. S., \& Matson, J. L. (2011). Anxiety symptoms across the lifespan in people diagnosed with autistic disorder. Research in Autism Spectrum Disorders, 5, 112-118. doi: 10.1016/j.rasd .2010 .02 .006

Elsabbaugh, M., Divan, G., Koh, Y.-J., Kim, S., Kauchali, S., Marcin, C.,...Fombonne, E. (2012). Global prevalence of autism and other pervasive developmental disorders. Autism Research, 5, 160-179. doi: 10.1002/aur.239

Forrester-Jones, R., \& Broadhurst, S. (2007). Autism and loss. Philadelphia, PA: Jessica Kingsley Publishers. 
Gray, C. (2010). The new social story book. Arlington, TX: Future Horizons.

Gresham, F. M., Sugai, G., \& Horner, R. H. (2001). Interpreting outcomes of social skills training for students with high-incidence disabilities. Exceptional Children, 67, 331-344. doi: $10.1177 / 001440290106700303$

Himebauch, A., Arnold, R. M., \& May, C. (2008). Grief in children and developmental concepts of death \#138. Journal of Palliative Medicine, 11(2), 242-243. doi:10.1089/jpm.2008.9973

Helbert, K. (2013). Finding your own way to grieve: A creative activity workbook for kids and teens on the autism spectrum. Philadelphia, PA: Jessica Kingsley Publishers.

Johnson, K. B. (2017). I don't like the talking part: The use of videogames to facilitate grief therapy for adolescents with autism spectrum disorder. Dissertation Abstracts International, 77(10-B)(E).

Jones, A. P., \& Frederickson, N. (2010). Multi-informant predictors of social inclusion for students with autism spectrum disorders attending mainstream school. Journal of Autism and Developmental Disorders, 40, 1094-1103. doi: 10.1007/s10803-010-0957-3

Kanner, L. (1943). Autistic disturbances of affective contact. Nervous Child, 2, 217-250.

Kasari, C., Locke, J., Gulsrud, A., \& Rotheram-Fuller, E. (2011). Social networks and friendships at school: Comparing children with and without autism. Journal of Autism and Developmental Disorders, 41, 533-544. doi: 10.1007/s10803-010-1076-X.

Kellems, R. O., \& Morningstar, M. E. (2012). Using video modeling delivered through iPods to teach vocational tasks to young adults with autism spectrum disorders. Career Development and Transition for Exceptional Individuals, 35, 155-167. doi: $\underline{10.1177 / 0885728812443082}$ 
Kerns, C. M., \& Kendall, P. C. (2012). The presentation and classification of anxiety in autism spectrum disorder. Clinical Psychology: Science and Practice, 19, 323-347. doi:

\section{$\underline{10.1111 / \mathrm{cpsp} .12009}$}

Kerns, C. M., Kendall, P. C., Berry, L., Souders, M. C., Franklin, M. E., Schultz, R. T., ...Herrington, J. (2014). Traditional and atypical presentations of anxiety in youth with autism spectrum disorder. Journal of Autism and Developmental Disorders, 44, 28512861. http://dx.doi.org/10.1007/s10803-014-2141-7

Kerns, C. M., Kendall, P. C., Zickgraf, H., Franklin, M. E., Miller, J., \& Herrington, J. (2015). Not to be overshadowed or overlooked: Functional impairments associated with comorbid anxiety disorders in youth with ASD. Behavior Therapy, 46, 29-39. doi:

\subsection{6/j.beth.2014.03.005}

Kerns, C. M., Newschaffer, C. J., \& Berkowitz, S. J. (2015). Traumatic childhood events and autism spectrum disorder. Journal of Autism and Developmental Disorders, 45, 34753486. doi: 10.1007/s10803-015-2392-y

Kerns, C. M., Rump, K., Worley, J., Kratz, H., McVey, A., Herrington, J., \& Miller, J. (2016). The differential diagnosis of anxiety disorders in cognitively-able youth with autism. Cognitive and Behavioral Practice, 23, 530-547. doi:10.1016/j.cbpra.2015.11.004

Kerns, C. M., Wood, J. J., Kendall, P. C., Renno, P., Crawford, E. A., Mercado, R. J., ...Storch, E. A. (2016). The treatment of anxiety in autism spectrum disorder (TAASD) study: Rationale, design and methods. Journal of Child and Family Studies, 25, 1889-1902. doi: $\underline{10.1007 / \mathrm{s} 10826-016-0372-2}$ 
Knight, V., Sartini, E., \& Spriggs, A. (2015). Evaluating visual activity schedules as evidencebased practice for individuals with autism spectrum disorders. Journal of Autism \& Developmental Disorders, 45, 157-178. doi: 10.1007/s10803-014-2201-z

Krantz, P. J., \& McClannahan, L. E. (1993). Teaching children with autism to initiate to peers: Effects of a script-fading procedure. Journal of Applied Behavior Analysis 26, 121-132. doi: 10.1901/jaba.1993.26-121

Krasny, L., Williams, B. J., Provencal, S., \& Ozonoff, S. (2003). Social skills interventions for the autism spectrum: Essential ingredients and a model curriculum. Child and Adolescent Psychiatric Clinics of North America, 12, 107-122. doi: 10.1016/S1056-4993(02)00051$\underline{2}$

Laugeson, E. A., Frankel, F., Mogil, C., \& Dillon, A. R. (2009). Parent-assisted social skills training to improve friendships in teens with autism spectrum disorders. Journal of Autism \& Developmental Disorders, 39, 596-606. doi: 10.1007/s10803-008-0664-5

Lipscomb, S., Haimson, J., Liu, A.Y., Burghardt, J., Johnson, D.R., \& Thurlow, M.L. (2017). Preparing for life after high school: The characteristics and experiences of youth in special education. Findings from the National Longitudinal Transition Study 2012. Volume 2: Comparisons across disability groups: Full report (NCEE 2017-4018). Washington, DC: U.S. Department of Education, Institute of Education Sciences, National Center for Education Evaluation and Regional Assistance.

Lipsky, D. (2013). How people with autism grieve and how to help. Philadelphia, PA: Jessica Kingsley Publishers.

Locke, J., Ishijima, E. H., Kasari, C., \& London, N. (2010). Loneliness, friendship quality and the social networks of adolescents with high-functioning autism in an inclusive school 
setting. Journal of Research in Special Educational Needs, 10, 74-81. doi:

\subsection{1/j.1471-3802.2010.01148.x}

Locke, J., Williams, J., Shih, W., \& Kasari, C. (2017). Characteristics of socially successful elementary school-aged children with autism. Journal of Child Psychology \& Psychiatry, 58,94-102. doi: 10.1111/jcpp.12636

Luxford, S., Hadwin, J. A., \& Kovshoff, H. (2016). Evaluating the effectiveness of a schoolbased cognitive behavioural therapy intervention for anxiety in adolescents diagnosed with autism spectrum disorder. Journal of Autism and Developmental Disorders.doi: $\underline{10.1007 / \mathrm{s} 10803-016-2857-7}$

Maich, K., \& Belcher, E. C. (2012). Using picture books to create peer awareness about autism spectrum disorders in the inclusive classroom. Intervention in School and Clinic, 47, 206-213. doi: $10.1177 / 1053451211424600$

Majoko, T. (2016). Inclusion of children with autism spectrum disorders: Listening and hearing to voices from the grassroots. Journal of Autism \& Developmental Disorders, 46, 14291440. doi: 10.1007/s10803-015-2685-1

Mason, J., \& Scior, K. (2004). 'Diagnostic overshadowing' amongst clinicians working with people with intellectual disabilities in the UK. Journal of Applied Research in Intellectual Disabilities, 17, 85-90. doi: 10.1111/j.1360-2322.2004.00184.x

McCoy, K., \& Hermansen, E. (2007). Video modeling for individuals with autism: A review of model types and effects. Education and Treatment of Children, 30, 183-213. doi: $\underline{10.1353 / \text { etc. } 2007.0029}$ 
McCrimmon, A. W., Matchullis, R. L., \& Altomare, A. A. (2016). Resilience and emotional intelligence in children with high-functioning autism spectrum disorder. Developmental Neurorehabilitation, 19, 154-161. doi:10.3109/17518423.2014.927017

McNally Keehn, R. H., Lincoln, A. J., Brown, M. Z., \& Chavira, D. A. (2013). The Coping Cat program for children with anxiety and autism spectrum disorder: A pilot randomized controlled trial. Journal of Autism and Developmental Disorders, 43, 57-67. doi: 10.1007/s10803-012-1541-9

National Autism Center (2015a). Findings and conclusions: National Standards Project: Addressing the need for evidence-based guidelines for autism spectrum disorder, phase 2. Randolph, MA: Author. Retrieved from http://www.nationalautismcenter.org/090605-2/

National Autism Center. (2015b). Evidence-based practice and autism in the schools: An educator's guide to providing appropriate interventions to students with autism spectrum disorder (2nd ed.). Randolph, MA: Author. Retrieved from http://www.nationalautismcenter.org/resources/for-educators/

Ochs, E., Kremer-Sadlik, T., Solomon, O., \& Sirota, K. G. (2001). Inclusion as social practice: Views of children with autism. Social Development, 10, 339-419. doi: 10.1111/14679507.00172

Ozonoff, S., Dawson, G., \& McPartland, J. (2002). A parent's guide to Asperger syndrome and high-functioning autism: How to meet the challenges and help your child thrive. New York, NY: Guilford Press.

Reaven, J., Blakely-Smith, A., Culhane-Shelburne, K., Hepburn, S. (2012) Group cognitive behavior therapy for children with high-functioning autism spectrum disorders and 
anxiety: A randomized trial. Journal of Child Psychology and Psychiatry, 53, 410-419. doi: $10.1111 / \mathrm{j} .1469-7610.2011 .02486 . x$

Renno, P., \& Wood, J. J. (2013). Discriminant and convergent validity of the anxiety construct in children with autism spectrum disorders. Journal of Autism and Developmental Disorders, 43, 2135-2146. doi: 10.1007/s10803-013-1767-1

Rosen, T. E., Connell, J. E., \& Kerns, C. M. (2016). A review of behavioral interventions for anxiety-related behaviors in lower-functioning individuals with autism. Behavioral Interventions, 31, 120-143. doi:10.1002/bin.1442

Schohl, K. A., Van Hecke, A. V., Carson, A. M., Dolan, B., Karst, J., \& Stevens, S. (2014). A replication and extension of the PEERS intervention: Examining effects on social skills and social anxiety in adolescents with autism spectrum disorders. Journal of Autism and Developmental Disorders, 44, 532-545. doi: 10.1007/s10803-013-1900-1

Sormanti, M. \& Ballan, M.S. (2011). Strengthening grief support for children with developmental disabilities. School Psychology International 32 (2) 179-193. doi:

\section{$\underline{10.1177 / 0143034311400831}$}

Stary, A. K., Everett, G. E., Sears, K. B., Fujiki, M., \& Hupp, S. A. (2012). Social stories for children with autism spectrum disorders: Updated review of the literature from 2004 to 2010. Journal of Evidence-Based Practices for Schools, 13, 123-140.

Sukhodolsky, D. G., Bloch, M. H., Panza, K. E., \& Reichow, B. (2013). Cognitive-behavioral therapy for anxiety in children with high-functioning autism: A meta-analysis. Pediatrics, 132(5), e1341-e1350. doi: 10.1542/peds.2013-1193

Storch, E. A., Arnold, E. B., Lewin, A. B., Nadeau, J. M., Jones, A. M., De Nadai, A. S., \& ... Murphy, T. K. (2013). The effect of cognitive-behavioral therapy versus treatment as 
usual for anxiety in children with autism spectrum disorders: A randomized, controlled trial. Journal of The American Academy of Child \& Adolescent Psychiatry, 52(2), 132142. doi:10.1016/j.jaac.2012.11.007

Sze, K. M., \& Wood, J. J. (2007). Cognitive behavioral treatment of comorbid anxiety disorders and social difficulties in children with high-functioning autism: A case report. Journal of Contemporary Psychotherapy, 37, 133-143. doi: 10.1007/s10879-007-9048-y

Tager-Flusberg, H., \& Joseph, R. M. (2003). Identifying neurocognitive phenotypes in autism. Philosophical Transactions of the Royal Society B: Biological Sciences, 358, 303-314. doi: $10.1098 /$ rstb.2002.1198

Ung, D., Selles, R., Small, B. J., \& Storch, E. A. (2015). A systematic review and meta-analysis of cognitive-behavioral therapy for anxiety in youth with high-functioning autism spectrum disorders. Child Psychiatry and Human Development, 46, 533-547. doi:

\section{$\underline{10.1007 / \mathrm{s} 10578-014-0494-\mathrm{y}}$}

van Steensel, F. J. A., Bögels, S. M., \& Perrin, S. (2011). Anxiety disorders in children and adolescents with autistic spectrum disorders: A meta-analysis. Clinical Child and Family Psychology Review, 14, 302-317. doi: 10.1007/s10567-011-0097-0

van Steensel, F.J.A., Heeman, E. J. (2017) Anxiety levels in children with autism spectrum disorder: A meta-analysis. Journal of Child and Family Studies, doi:10.1007/s10826-017$\underline{0687-7}$

Wharff, J. (2015). Helping kids with autism understand death. Retrieved from http://blog.stageslearning.com/blog/understanding-death

Wheeler, M. (2016). Supporting individuals on the autism spectrum coping with grief and loss through death or divorce. The Reporter, 20 (20). Retrieved from 
https://www.iidc.indiana.edu/pages/supporting-individuals-on-the-autism-spectrum-

coping-with-grief-and-loss

White, S. W., Oswald, D., Ollendick, T., \& Scahill, L. (2009). Anxiety in children and adolescents with autism spectrum disorders. Clinical Psychology Review, 29, 216-229. doi: 10.1016/j.cpr.2009.01.003

Williams White, S., Keonig, K., \& Scahill, L. (2007). Social skills development in children with autism spectrum disorders: A review of the intervention research. Journal of Autism and Developmental Disorders, 37, 1858-1868. doi: 10.1007/s10803-006-0320-x

Wood, J., Ehrenreich-May, J., Allesandri, M., Fujii, C., Renno, P., Laugeson, E., . . . Storch, E.A. (2015). Cognitive behavioral therapy for early adolescents with autism spectrum disorders and clinical anxiety: A randomized, clinical trial. Behavior Therapy 46 (1), 719. doi: $10.1016 / j . b e t h .2014 .01 .002$

Wood, J, Drahota, A, Sze, K., Har, K., Chiu, A, Langer, D.A. (2009). Cognitive behavioral therapy for anxiety in children with autism spectrum disorders: A randomized control trial. Journal of Child Psychology and Psychiatry 50 (3), 224-234. doi: 10.1111/j.14697610.2008.01948.x

Yoo, H., Bahn, G., Cho, I., Kim, E., Kim, J., Min, J., \& ... Laugeson, E. A. (2014). A randomized controlled trial of the Korean version of the PEERS® parent-assisted social skills training program for teens with ASD. Autism Research, 7, 145-161. doi: 10.1002/aur.1354 
Table 1

Resources for Anxiety: Supporting Children with Autism

\begin{tabular}{|c|c|c|c|}
\hline Resource & Reference & Information provided & $\begin{array}{l}\text { Resource } \\
\text { relevance }\end{array}$ \\
\hline $\begin{array}{l}\text { Autism speaks: Managing anxiety in children with autism } \\
\text { https://www.autismspeaks.org/blog/2014/05/29/managing- } \\
\text { anxiety-children-autism }\end{array}$ & Wood, J. (n.d.) & $\begin{array}{l}\text { Short article about what } \\
\text { anxiety looks like in children } \\
\text { with autism, links to articles } \\
\text { and books, link to find } \\
\text { therapists, links to toolkits }\end{array}$ & $\begin{array}{l}\text { Parent, } \\
\text { Educator, } \\
\text { Therapist }\end{array}$ \\
\hline $\begin{array}{l}\text { When my worries get too big! A relaxation book for } \\
\text { children who live with anxiety }\end{array}$ & $\begin{array}{l}\text { Buron, K. D. } \\
(2006)\end{array}$ & $\begin{array}{l}\text { Picture book with activities } \\
\text { based on the 5-point scale and } \\
\text { anxiety curve, developmental } \\
\text { age } 5-10\end{array}$ & $\begin{array}{l}\text { Children's } \\
\text { book }\end{array}$ \\
\hline $\begin{array}{l}\text { Indiana Resource Center for Autism: Anxiety and Autism } \\
\text { Spectrum Disorders } \\
\text { https://www.iidc.indiana.edu/pages/anxiety-and-autism- } \\
\text { spectrum-disorders }\end{array}$ & Merrill, A. (n.d.) & $\begin{array}{l}\text { Explanation of anxiety in } \\
\text { autism, treatment options, links } \\
\text { to other websites, additional } \\
\text { resources including helpful } \\
\text { apps }\end{array}$ & Parent \\
\hline $\begin{array}{l}\text { Exploring feelings: Anxiety: Cognitive Behaviour Therapy } \\
\text { to manage anxiety } \\
\text { See Appendix B for more information. }\end{array}$ & $\begin{array}{l}\text { Attwood, T. } \\
(2004)\end{array}$ & $\begin{array}{l}\text { Guide for learning about } \\
\text { emotions to help children } \\
\text { connect the thoughts, feelings, } \\
\text { and behaviors they experience } \\
\text { related to anxiety }\end{array}$ & $\begin{array}{l}\text { Parent, } \\
\text { Therapist }\end{array}$ \\
\hline $\begin{array}{l}\text { Cognitive-Behavioral Therapy for anxious children: } \\
\text { Therapist Manual ( } 3 \mathrm{rd} \text { ed.) } \\
\text { See Appendix B for more information. }\end{array}$ & $\begin{array}{l}\text { Kendall, P. C., \& } \\
\text { Hedtke, K. A. } \\
(2006)\end{array}$ & $\begin{array}{l}\text { Evidence-based manual for } \\
\text { therapists to target anxiety } \\
\text { symptoms using cognitive- } \\
\text { behavioral therapy techniques, } \\
\text { the Coping Cat curriculum }\end{array}$ & Therapist \\
\hline
\end{tabular}


Resources were chosen by prioritizing those that were free or low cost, those available in multiple languages, those with established evidence base, or those commonly used in practice. Resources listed are available via Internet, online booksellers, website or other information about availability is provided. All resources listed are available via Internet, online booksellers, or website provided. For additional resources refer to Appendix B [insert link to Appendix B here 
Table 2

Resources for Social Isolation: Supporting Children with Autism

\begin{tabular}{|c|c|c|c|}
\hline Resource & Reference & Information about resource & $\begin{array}{l}\text { Type of } \\
\text { resource }\end{array}$ \\
\hline $\begin{array}{l}\text { We're amazing 1,2,3! } \\
\text { http://autism.sesamestreet.org/storybook- } \\
\text { we-are-amazing }\end{array}$ & $\begin{array}{l}\text { Kimmelman, } \\
\text { L., \& Nelson, } \\
\text { M. (n.d.) }\end{array}$ & $\begin{array}{l}\text { Sesame street book to introduce a new character with } \\
\text { ASD and how to include her in play }\end{array}$ & $\begin{array}{l}\text { Children's } \\
\text { book (online) }\end{array}$ \\
\hline $\begin{array}{l}\text { Superflex: A superhero social thinking } \\
\text { curriculum } \\
\text { https://www.socialthinking.com/ }\end{array}$ & $\begin{array}{l}\text { Madrigal, S., \& } \\
\text { Winner, M. G. } \\
\text { (2008) }\end{array}$ & $\begin{array}{l}\text { Curriculum using comic book characters to teach skills } \\
\text { in cognitive thinking, social behaviors, and self- } \\
\text { regulation; comes with manual, first comic book; CD } \\
\text { for individualizing the curriculum }\end{array}$ & $\begin{array}{l}\text { Educator, } \\
\text { parent, } \\
\text { therapist } \\
\text { +children's } \\
\text { book }\end{array}$ \\
\hline $\begin{array}{l}\text { The PEERS@ curriculum for school-based } \\
\text { professionals: Social skills training for } \\
\text { adolescents with autism spectrum disorder } \\
\text { (1st ed.) } \\
\text { https://www.semel.ucla.edu/peers }\end{array}$ & $\begin{array}{l}\text { Laugeson, E., \& } \\
\text { Frankel, F. } \\
(2013)\end{array}$ & $\begin{array}{l}\text { Weekly social skills direct instruction curriculum for } \\
\text { adolescents with ASD; group format; also available in } \\
\text { school-based and Korean language versions }\end{array}$ & $\begin{array}{l}\text { Educator, } \\
\text { therapist }\end{array}$ \\
\hline $\begin{array}{l}\text { The new social story book (10th ed.) } \\
\text { http://carolgraysocialstories.com/ }\end{array}$ & Gray, C. (2010) & $\begin{array}{l}\text { Specific methods for constructing effective social } \\
\text { stories; examples of social stories for a variety of } \\
\text { situations }\end{array}$ & $\begin{array}{l}\text { Parent, } \\
\text { educator, } \\
\text { therapist }\end{array}$ \\
\hline
\end{tabular}

Resources were chosen by prioritizing those that were free or low cost, those available in multiple languages, those with established evidence base, or those commonly used in practice. Resources listed are available via Internet, online booksellers, website or other 
information about availability is provided. For additional parent, educator, and therapist resources that address social isolation, see Appendix C [insert link to Appendix C] 
Table 3

Resources for Grief: Supporting Children with Autism

\begin{tabular}{|c|c|c|c|}
\hline Resource & Reference & Information about resource (ages are developmental age) & $\begin{array}{l}\text { Type of } \\
\text { resource }\end{array}$ \\
\hline $\begin{array}{l}\text { Help me say goodbye: Activities } \\
\text { for helping kids cope when a } \\
\text { special person dies }\end{array}$ & Silverman, J. (1999) & $\begin{array}{l}\text { Activity book includes art activities to help children } \\
\text { cope with grief }\end{array}$ & $\begin{array}{l}\text { Children's } \\
\text { Book }\end{array}$ \\
\hline $\begin{array}{l}\text { What on earth do you do when } \\
\text { someone dies? }\end{array}$ & Romain, T. (1999) & $\begin{array}{l}\text { Story addresses the topic of death and offers comfort and } \\
\text { reassurance; ages } 5-10\end{array}$ & $\begin{array}{l}\text { Children's } \\
\text { book }\end{array}$ \\
\hline When a pet dies & Rogers, F. (1998) & $\begin{array}{l}\text { Story helps explain the death of a pet, what events might } \\
\text { occur, and what feelings a child might have; ages } 4-8\end{array}$ & $\begin{array}{l}\text { Children's } \\
\text { book }\end{array}$ \\
\hline
\end{tabular}

Children's books were chosen because they were short in length, included concrete language, and were straightforward.

Additional resources were chosen to help therapists, parents, and educators provide hands-on activities and

straightforward information about death and loss. For additional parent, educator, and therapist resources, see Appendix

D [insert link to Appendix D here]. 


\section{Appendix A: Recommended Readings: Learning Strategies to Support Children with Autism}

Selected from: National Autism Center. (2015). Evidence-based practice and autism in the schools: An educator's guide to providing appropriate interventions to students with autism spectrum disorder (2nd ed.). Randolph, MA: Author. Retrieved from http://www.nationalautismcenter.org/resources/for-educators/

\begin{tabular}{|c|c|c|c|}
\hline Resource & Reference & Information about resource & $\begin{array}{l}\text { Type of } \\
\text { resource }\end{array}$ \\
\hline $\begin{array}{l}\text { Visual supports for people with autism: A guide for } \\
\text { parents and professionals }\end{array}$ & $\begin{array}{l}\text { Cohen, M. J., \& Sloan, D. } \\
\text { L. (2007) }\end{array}$ & $\begin{array}{l}\text { How-to-guide to create and use a variety of visual } \\
\text { supports; includes visual activity schedules }\end{array}$ & $\begin{array}{l}\text { Parent, } \\
\text { educator, } \\
\text { therapist }\end{array}$ \\
\hline $\begin{array}{l}\text { Visual strategies for improving communication (revised } \\
\& \text { updated edition): Practical Supports for Autism } \\
\text { Spectrum Disorders }\end{array}$ & Hodgdon, L. A. (2011) & $\begin{array}{l}\text { Reader-friendly, comprehensive coverage of using } \\
\text { visual strategies to improve communication for } \\
\text { students with ASD; includes easy to use strategies }\end{array}$ & $\begin{array}{l}\text { Parent, } \\
\text { educator, } \\
\text { therapist }\end{array}$ \\
\hline $\begin{array}{l}\text { Activity schedules for children with autism: Teaching } \\
\text { independent behavior ( } 2 \text { nd ed.) }\end{array}$ & $\begin{array}{l}\text { McClannahan, L. E., \& } \\
\text { Krantz, P. J. (2010) }\end{array}$ & $\begin{array}{l}\text { How-to-guide for visual schedules with the goal of } \\
\text { increasing independence }\end{array}$ & $\begin{array}{l}\text { Parent, } \\
\text { educator, } \\
\text { therapist }\end{array}$ \\
\hline $\begin{array}{l}\text { Seeing is believing: Video self-modeling for people with } \\
\text { autism and other developmental disabilities }\end{array}$ & Buggey, T. (2009) & $\begin{array}{l}\text { How-to-guide for video modeling interventions to } \\
\text { build skills }\end{array}$ & $\begin{array}{l}\text { Parent, } \\
\text { educator, } \\
\text { therapist }\end{array}$ \\
\hline $\begin{array}{l}\text { Video modeling for young children with autism spectrum } \\
\text { disorder: A practical guide for parents and professionals }\end{array}$ & $\begin{array}{l}\text { Murray, S., \& Nolan, B. } \\
\text { (2013) }\end{array}$ & $\begin{array}{l}\text { How-to-guide for video modeling interventions to } \\
\text { build skills }\end{array}$ & $\begin{array}{l}\text { Parent, } \\
\text { educator, } \\
\text { therapist }\end{array}$ \\
\hline $\begin{array}{l}\text { Video modelling and behaviour analysis: A guide for } \\
\text { teaching social skills to children with autism }\end{array}$ & $\begin{array}{l}\text { Nikopoulos, C., \& Keenan, } \\
\text { M. (2006) }\end{array}$ & $\begin{array}{l}\text { How-to-guide for video modeling as an applied } \\
\text { behavior analysis technique for building social } \\
\text { skills }\end{array}$ & $\begin{array}{l}\text { Parent, } \\
\text { educator, } \\
\text { therapist }\end{array}$ \\
\hline $\begin{array}{l}\text { Teaching conversation to children with autism: scripts } \\
\text { and script fading (topics in autism) }\end{array}$ & $\begin{array}{l}\text { McClannahan, L. E., \& } \\
\text { Krantz, P. J. (2005) }\end{array}$ & $\begin{array}{l}\text { Social scripts and how to promote natural } \\
\text { conversation by using applied behavioral } \\
\text { technique of fading }\end{array}$ & $\begin{array}{l}\text { Parent, } \\
\text { educator, } \\
\text { therapist }\end{array}$ \\
\hline
\end{tabular}


Teach me with pictures: 40 fun picture scripts to develop play and communication skills in children on the autism spectrum
Griffin, S., Harris, R., \& Hogdon, L. (2013)
Using visual prompts for scripting and social communication
Parent, educator, therapist 
Appendix B: Anxiety Resources to Support Children with Autism

\begin{tabular}{l} 
Resource \\
\hline Mom, dad, come back soon \\
$\begin{array}{l}\text { My anxious mind: A teen's guide to managing anxiety } \\
\text { and panic }\end{array}$
\end{tabular}
and panic

\section{Sometimes I'm scared}

What to do when you worry too much: A kid's guide to overcoming anxiety

\section{When Fuzzy was afraid of big and loud things}

When Lizzy was afraid of trying new things

Coping cat workbook (2nd ed.)

Coping cat parent companion

The C.A.T. project manual for the cognitive behavioral treatment of anxious adolescents

Reference
Pappas, D. (2001)
Tompkins, M. A. \&
Martinez, K. A., Sloan,
M. (2009)
Annunziata, J.,
Nemiroff, M., \& Langdo,
B. (2009)
Huebner, D., \&
Matthews, B. (2005)
Maier, I., \& Candon, J.
(2006)

(2006)

Maier, I., \& Candon, J. (2005)

Kendall, P., \& Hedtke, K. A. (2006)

Kendall, P. (2010)

Kendall, P. C., Choudhury, M., Hudson, J., \& Webb, A. (2002)

\section{Information about resource
(ages are developmental age)}

Picture book to help children who struggle with being

separated from their parents; ages 4-8

Book based on cognitive-behavioral strategies,

designed to help teens with their anxious feelings;

ages $12-18$

Picture book about understanding fears; includes tips to overcoming common childhood fears; also

available in Chinese, ages 5-8

Interactive self-help picture book that teaches cognitive-behavioral techniques to help children overcome generalized anxiety; ages 6-12

Picture book about dealing with common fears, uses behavioral techniques; also available in Chinese, ages 2 and older

Picture book about dealing with fear of making mistakes and failing; ages 2 and older

Children's book

Children's workbook manual-Cognitive-behavioral therapy for anxious children: Therapist manual (3rd ed.); ages 7-13

Parent manual to accompany the Coping cat therapy manual-Cognitive-behavioral therapy for anxious children: Therapist manual (3rd ed.); ages 7-13

Parent manual

Coping cat curriculum adapted for adolescents

Therapist manual 
The C.A.T. project workbook

Behavioral interventions for anxiety in children with autism (BIACA)

The cool kids family program: Therapist manual ${ }^{\mathrm{a}}$ https://shop.centreforemotionalhealth.com.au/productcategory/forprofessionals/clinical/

Modular cognitive-behavioral therapy for childhood anxiety disorders ${ }^{\mathrm{b}}$

CBT for children and adolescents with high functioning autism spectrum disorders ${ }^{b}$
Kendall, P. (2002)

Wood J. J., et al. Public release expected via Internet 2019

Lyneham, H. J., Abbott,

M. J., Wignall A., \& Rapee, R. M. (2003)

Chorpita, B. F. (2007)

Scarpa, A., White, S. W., \& Attwood, T. (Eds.). (2016)
Teen workbook that accompanies the The C.A.T. project manual

Cognitive behavior therapy strategies adapted for children with autism

Cognitive behavior therapy strategies adapted for children with autism

Cognitive behavioral therapy manual for anxiety reduction

Therapist manual

Therapist manual

Teen workbook

Therapist manual

Therapist manual

Cognitive behavior therapy manual for anxiety reduction

${ }^{a}$ Included in Ung, D., Selles, R., Small, B. J., \& Storch, E. A. (2015). A systematic review and meta-analysis of cognitive-behavioral therapy for anxiety in youth with high-functioning autism spectrum disorders. Child Psychiatry and Human Development, 46(4), 533-547. doi:10.1007/s10578-014-0494-y

${ }^{\mathrm{b}}$ Recommended readings from National Autism Center. (2015). Evidence-based practice and autism in the schools: An educator's guide to providing appropriate interventions to students with autism spectrum disorder (2nd ed.). Randolph, M. A. Retrieved from http://www.nationalautismcenter.org/resources/for-educators/00

Resources were chosen by prioritizing those that were free or low cost, those available in multiple languages, those with established evidence base, or those commonly used in practice. Resources listed are available via Internet, online booksellers, website or other information about availability is provided. 
Appendix C: Social Isolation Resources to Support Children with Autism

\begin{tabular}{|c|c|c|c|}
\hline Resource & Reference & $\begin{array}{l}\text { Information about resource } \\
\text { (ages are developmental age) }\end{array}$ & Type of resource \\
\hline $\begin{array}{l}\text { My mouth is a volcano and My mouth is } \\
\text { a volcano activity and idea book }\end{array}$ & $\begin{array}{l}\text { Cook, J. \& Hartman, } \\
\text { C. }(2006,2009)\end{array}$ & $\begin{array}{l}\text { Picture book focusing on strategies to reduce interrupting } \\
\text { others, increase listening to others and respecting when it is } \\
\text { someone else's turn to speak; ages 5-8 }\end{array}$ & $\begin{array}{l}\text { Children's book and } \\
\text { Parent, educator, } \\
\text { therapist resource }\end{array}$ \\
\hline $\begin{array}{l}\text { Diary of a social detective: Real life } \\
\text { tales of mystery, intrigue and } \\
\text { interpersonal adventure }\end{array}$ & Jessum, J. (2011) & $\begin{array}{l}\text { Humorous youth novel about an older, experienced boy with } \\
\text { ASD who is teaching the younger students how to solve the } \\
\text { mystery of what is appropriate social behavior; ages } 8 \text { and older }\end{array}$ & $\begin{array}{l}\text { Children's chapter } \\
\text { book }\end{array}$ \\
\hline Waiting for Benjamin ${ }^{a}$ & $\begin{array}{l}\text { Altman, A., \& } \\
\text { Keeter, S. (2008) }\end{array}$ & $\begin{array}{l}\text { Picture book about a boy who learns patience with his younger } \\
\text { brother who has ASD; ages 4-9 }\end{array}$ & $\begin{array}{l}\text { Children's book for } \\
\text { peers and siblings }\end{array}$ \\
\hline $\begin{array}{l}\text { Playing by the rules: A story about } \\
\text { autism }^{\text {a }}\end{array}$ & $\begin{array}{l}\text { Luchsinger, D., \& } \\
\text { Olson, J. (2007) }\end{array}$ & $\begin{array}{l}\text { Story of how children can bridge the gap between their sibling } \\
\text { with ASD and others; ages } 4 \text { and older }\end{array}$ & $\begin{array}{l}\text { Children's book for } \\
\text { siblings }\end{array}$ \\
\hline Autism and me: Sibling stories ${ }^{a}$ & Shapiro, O. (2009) & Collection of essays by siblings of children with ASD; ages 8-12 & $\begin{array}{l}\text { Children's book for } \\
\text { siblings and peers }\end{array}$ \\
\hline Andy and his yellow frisbee ${ }^{a}$ & $\begin{array}{l}\text { Thompson, M. } \\
\text { (1996) }\end{array}$ & $\begin{array}{l}\text { Story of a girl who is curious about a boy with ASD and how his } \\
\text { sister explains ASD }\end{array}$ & $\begin{array}{l}\text { Children's book for } \\
\text { siblings and peers }\end{array}$ \\
\hline $\begin{array}{l}\text { Understanding Sam and Asperger } \\
\text { syndrome }{ }^{a}\end{array}$ & $\begin{array}{l}\text { Van Nierkerk, C., \& } \\
\text { Venter, L. (2006) }\end{array}$ & $\begin{array}{l}\text { Story about Sam, who has ASD, and how we can learn to help } \\
\text { him without expecting him to change to suit our expectations; } \\
\text { ages } 5-8\end{array}$ & $\begin{array}{l}\text { Children's book for } \\
\text { peers }\end{array}$ \\
\hline $\begin{array}{l}\text { Why does Izzy cover her ears? Dealing } \\
\text { with sensory overload }^{\text {a }}\end{array}$ & $\begin{array}{l}\text { Veenendall, J. } \\
\text { (2009) }\end{array}$ & Picture book addressing sensory sensitivities; ages $4-8$ & $\begin{array}{l}\text { Children's book for } \\
\text { peers }\end{array}$ \\
\hline $\begin{array}{l}\text { Arnie and his school tools: Simple } \\
\text { sensory solutions that build success }\end{array}$ & $\begin{array}{l}\text { Veenendall, J. } \\
\text { (2008) }\end{array}$ & $\begin{array}{l}\text { Picture book explaining what it feels like to have sensory } \\
\text { sensitivities; ages 6-12 }\end{array}$ & $\begin{array}{l}\text { Children's book for } \\
\text { peers }\end{array}$ \\
\hline $\begin{array}{l}\text { A } 5 \text { is against the law! Social } \\
\text { boundaries straight-up: An honest } \\
\text { guide for teens and young adults }\end{array}$ & Buron, K. D. (2007) & $\begin{array}{l}\text { Concrete framework (5-point scale) for understanding that } \\
\text { some actions are okay in some contexts, but can get you } \\
\text { arrested in other contexts; ages } 10 \text { and older }\end{array}$ & $\begin{array}{l}\text { Parent, educator, } \\
\text { therapist }\end{array}$ \\
\hline
\end{tabular}


The science of making friends: Helping socially challenged teens and young adults

All my stripes: A story for children with autism

A friend like Simon - Autism / ASD Special Stories Series 2 (Volume 1)

Social skills solutions: A hands-on manual for teaching social skills to children with autism ${ }^{\mathrm{b}}$

\section{Skillstreaming series: A guide for} teaching prosocial skills (3rd ed.)

Peer support strategies for improving all students' social lives and learning ${ }^{b}$

Facilitating play dates for children with autism and typically developing peers in natural settings: A training manual ${ }^{b}$

Superflex takes on Rock Brain and the team of unthinkables

Superflex takes on Glassman and the team of unthinkables
Laugeson, E. (2013)

Guide for coaching adolescents and young adults in finding friends and navigating intense social environments

Rudolph, S. \&

Royer, D. (2015)

Gaynot, K. 2009

McKinnon, K., \&

Krempa, J. L. (2002)

McGinnis, E. (2011)

Carter, E. W.

Cushing, L. S., \& Kennedy, C. H. (2008)

Reid, D. H., \&

Parsons, M. B. (2002)

Madrigal, S., \& Knopp, K. (2008)

Madrigal, S., \& Winner, M. G. (2009)
Picture book to help children understand their autism as a strength that makes them who they are

Story that encourages children to be patient with children with ASD and learn about their positive contributions to friendships (Moonbeam childrens book award winner 2009)

Social skills intervention manual

Curriculum for social skills instruction, early childhood, elementary, adolescent, and high-functioning versions; lesson plans; and student manuals also available

Instructions and research on establishing peer support networks

Guide for building social play skills

Comic book hero, Superflex, protects others from the unthinkables (villains who want to restrict flexible social thinking); Packaged with Superflex: A superhero social thinking curriculum; includes CD for individual practice lessons; ages 511

Superflex shows you how to fight against the villain, Glassman, who causes us to over-react to small things; ages 5-11
Parent, educator, therapist

\section{Children's book}

Children's book for peers

Educator, therapist

Educator, therapist manual

Educator manual

Parent, educator, therapist manual

Children's bookt therapist, educator, or parent manual

Children's book 
Superflex takes on Brain Eater and the team of unthinkables

Social town citizens discover 82 new unthinkables for Superflex to outsmart!

Superflex takes on one-sided Sid, Unwonderer and the team of unthinkables

Thinking about you thinking about me (2nd ed.)

You are a social detective
Madrigal, S., \& Winner, M. G. (2011)

Winner, M. G., Madrigal, S., \&

Crooke, P. (2012)

Winner, M. G., \&

Madrigal, S. (2014)

Winner, M. G. (2007)

Winner, M. G., \& Crooke, P. (2008)
Superflex takes on Brain Eater, who distracts kids from doing everyday tasks or listening to instructions; includes CD for practice lessons; ages 5-11

Comic book that is not a narrative, but catalog of how to defeat a variety of maladaptive thoughts and how to boost adaptive social thinking; ages 5-11

Superflex tackles people who only talk about themselves and people who never think about others; ages 5-11

Manual focused on strategies and activities to increase ability to take another person's perspective

Comic book format for teaching school smarts, social smarts, unexpected and expected behavior, and noticing social clues; ages 5-11
Children's book

Children's book

Children's book

Parent, educator, therapist manual

Children's book, best with adult help

\footnotetext{
${ }^{a}$ Titles included in Maich, K., \& Belcher, E. C. (2012). Using picture books to create peer awareness about autism spectrum disorders in the inclusive classroom. Intervention in School and Clinic, 47(4), 206-213.

${ }^{\mathrm{b}}$ Recommended readings from National Autism Center. (2015). Evidence-based practice and autism in the schools: An educator's guide to providing appropriate interventions to students with autism spectrum disorder (2nd ed.). Randolph, MA: Author. Retrieved from http://www.nationalautismcenter.org/resources/for-educators/
}

Resources were chosen by prioritizing those that were free or low cost, those available in multiple languages, those with established evidence base, or those commonly used in practice. Resources listed are available via Internet, online booksellers, website or other information about availability is provided. 


\section{Appendix D: Grief Resources to Support Children with Autism}

\begin{tabular}{lll}
\hline \multicolumn{1}{c}{ Resource } & \multicolumn{1}{c}{$\begin{array}{l}\text { Reference } \\
\text { resource }\end{array}$} & $\begin{array}{l}\text { Type of } \\
\text { restormation about resource } \\
\text { (ages are developmental age) }\end{array}$ \\
\hline $\begin{array}{l}\text { How people with autism grieve and how to help: An insider } \\
\text { handbook }\end{array}$ & Lipsky, D. (2013) & $\begin{array}{l}\text { Firsthand accounts and of what grief feels and } \\
\text { looks like in a person with ASD and ideas for } \\
\text { how to support }\end{array}$ \\
educator, \\
therapist
\end{tabular}

When someone dies: A child-caregiver activity book

Autism and loss

Bereavement and grief resources

https://www.autismspeaks.org/family-services/resource-

library/bereavement-and-grief-resources

Indiana Resource Center for Autism

https://www.iidc.indiana.edu/pages/supporting-individuals-on-

the-autism-spectrum-coping-with-grief-and-loss

Parent tips: Death and grieving

http://www.pathfindersforautism.org/articles/view/parent-tips-

death-and-grieving

Children's books were chosen because they were short in length, included concrete language, and were straightforward. Additional resources were chosen to help therapists, parents, and educators provide hands-on activities and straightforward information about death and loss.
National Alliance fo Grieving Children (2016)

Forrester-Jones, R.,

\& Broadhurst, $\mathrm{S}$

(2007)

Autism Speaks (n.d.)

Comprehensive listing of books and online resources

Wheeler, M. (n.d.)

Common reactions to death; support strategies; concrete activity examples; printable social stories; other resources

Grace, N., \& Allred, Articles; link to insider handbook; sample social story; links to other resources
Caregiver.

parent, child

Parent,

educator,

therapist

Family,

caregiver

Parents,

caregiver

Parents,

caregiver 